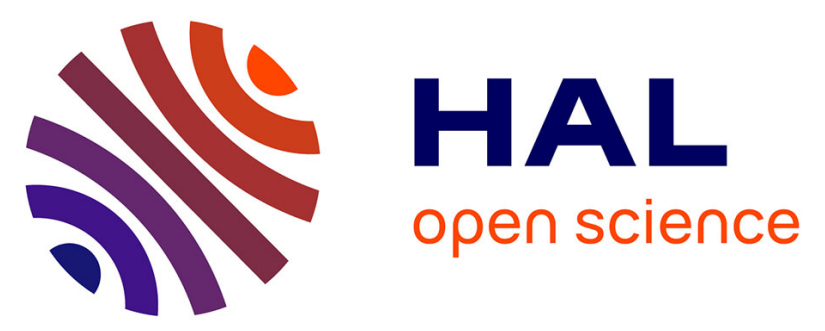

\title{
Hybrid fuel cell powered drones energy management strategy improvement and hydrogen saving using real flight test data
}

Mohamed Nadir Boukoberine, Muhammad Fahad Zia, Mohamed Benbouzid, Zhibin Zhou, Teresa Donateo

\section{To cite this version:}

Mohamed Nadir Boukoberine, Muhammad Fahad Zia, Mohamed Benbouzid, Zhibin Zhou, Teresa Donateo. Hybrid fuel cell powered drones energy management strategy improvement and hydrogen saving using real flight test data. Energy Conversion and Management, 2021, 236, pp.113987. 10.1016/j.enconman.2021.113987 . hal-03460679

\section{HAL Id: hal-03460679 \\ https://hal.science/hal-03460679}

Submitted on 1 Dec 2021

HAL is a multi-disciplinary open access archive for the deposit and dissemination of scientific research documents, whether they are published or not. The documents may come from teaching and research institutions in France or abroad, or from public or private research centers.
L'archive ouverte pluridisciplinaire HAL, est destinée au dépôt et à la diffusion de documents scientifiques de niveau recherche, publiés ou non, émanant des établissements d'enseignement et de recherche français ou étrangers, des laboratoires publics ou privés. 


\title{
Hybrid fuel cell powered drones energy management strategy improvement and hydrogen saving using real flight test data
}

\author{
Mohamed Nadir Boukoberine ${ }^{\mathrm{a}}$, Muhammad Fahad Zia ${ }^{\mathrm{b}}$, Mohamed Benbouzid ${ }^{\mathrm{a}, \mathrm{c}, *}$, Zhibin Zhou $^{\mathrm{d}}$, Teresa Donateo ${ }^{\mathrm{e}}$ \\ ${ }^{a}$ University of Brest, UMR CNRS 60 IRDL, 29238 Brest, France \\ ${ }^{b}$ Department of Electrical Engineering, National University of Computer and Emerging Sciences, 54000 Lahore, Pakistan \\ ${ }^{c}$ Shanghai Maritime University, 201306 Shanghai, China \\ 'dISEN Yncréa Ouest, L@bISEN, 29200 Brest,France \\ ${ }^{e}$ Department of Engineering for Innovation,University of Salento, 73100 Lecce, Italy
}

\begin{abstract}
This paper deals with hybrid electric fuel cell-powered drones energy management while targeting hydrogen saving and power supply system efficiency improvement. In this context, a commercially available quadcopter powered by the Intelligent Energy $650 \mathrm{~W}$ power module is adopted as a case study. Its power supply system is based on fuel cell and battery, and the power is conventionally managed using a basic rule-based strategy. To improve power management, a frequency separation rule-based approach is first proposed, and then an equivalent consumption minimization strategy is implemented for fuel economy seeking. An experimental flight test is carried out using a battery-powered hexacopter to extract a real power profile for load requirement modeling. The obtained load profile is repeated several times replicating the hovering phase to obtain a larger mission lifetime. Extensive simulation results clearly show that the proposed power management strategies enables power sources operating in their nominal area, extending their lifetimes, and inducing 3\% minimization in hydrogen consumption. This optimization extends the drone endurance as much as the carried fuel amount, and it can increase the world endurance record by $21.81 \mathrm{~min}$. It has also an economical benefit, which consists in the operating cost gain reaching $853.2 €$ per fuel cell module lifecycle. In fleet missions, this gain may further be increased.
\end{abstract}

Keywords: Multicopter drone, flight test, fuel cell, battery, hydrogen consumption minimization, drone endurance.

\section{Introduction}

Small electric drones are recently attracting the research community interest thanks to their increasing use in several industrial applications. Equipped by different tools and sensors, they can perform variety of tasks such as inspection and monitoring [1], delivery [2], agriculture tasks [3], wireless coverage [4], and they had also been useful in COVID-19 pandemic handling, by means of social distancing monitoring [5], thermal imaging and sanitization [6]. Great progress is being made in military field performing intelligence, surveillance, and reconnaissance missions to avoid human losses in dangerous situations $[7,8]$. They also have the added advantage of good operational characteristics such as high mobility, reliability, efficiency, and very reduced thermal and noise signatures.

Most of commercialized drones are powered by batteries as sole power source due to their low cost and simplicity. However, batteries have a relatively low energy density that results in short flight time of drone and obstruction of long and persistent missions [9]. Increasing batteries number or size can not be

\footnotetext{
${ }^{*}$ Corresponding author

Email addresses: MohamedNadir.Boukoberine@univ-brest.fr (Mohamed Nadir Boukoberine), fahad.zia@nu.edu.pk (Muhammad Fahad Zia), Mohamed.Benbouzid@univ-brest.fr (Mohamed Benbouzid), zhibin.zhou@isen-ouest. yncrea.fr (Zhibin Zhou), teresa.donateo@unisalento.it (Teresa Donateo)
}

a practical solution due to the weight constraint. Li-air batteries may offer a higher autonomy for drones [10], however, this technology is still not practically implementable. Therefore, the fuel cell is an alternative for batteries to provide a clean energy with much higher energy density [11]. Thus, the drone operation time will be increased and it will depend only on the fuel tank size. In addition, fast refueling will be possible as compared to batteries, which relatively need a longer charging time.

Donateo et al. [12] provided performance comparison between fuel cell- and battery-based drones power supply systems. The study has shown that battery-based system fits on low-energy applications while fuel cell provides much higher autonomy when the carried energy exceeds 4MJ. In another recent study [13], fuel cell hybrid system (FCHS) and batteries supplying multirotor drones have been analyzed. According to the proposed assessing model, FCHS performs better in terms of endurance when the power system mass is higher than a threshold of $7.3 \mathrm{~kg}$. Considering a commercially available multirotor with a maximum take-off mass of $25 \mathrm{~kg}$ as a case study, it was proved that endurance increases by $+76 \%$ using FCHS.

In this context, Singapore-based HES Energy Systems enterprise has launched their Hycopter multicopter for large-scale industrial maintenance inspections, the autonomy was increased from 20-30min provided by lithium-ion batteries to 3.5 hour using compressed gaseous hydrogen [14]. MetaVista, a South 
Korean-based company, recently completed a nearly $12 \mathrm{~h} 7 \mathrm{~min}$ multicopter test flight using an Intelligent Energy 800W fuel cell power module [15]. This is considered as the world longest flight time.

Depending on the mission requirement, the drone may perform some rapid maneuvers which need a fast power supply system response such as take-off and climbing. Due to its slow dynamics, a fuel cell system can not provide the appropriate response to that power peaks [16]. Therefore, combining the fuel cell with battery is proposed to improve the power supply performances. The battery is used as an energy buffer and will supply or absorb power peaks due to its relatively short response time. For example, this configuration is adopted for the Intelligent Energy 650W fuel cell power module in powering the DJI M100 quadcopter [17]. This hybridization requires an energy management strategy (EMS) to be implemented in order to optimize the power allocation respecting the sources characteristics and preserving their lifetimes.

A critical review addressing energy management strategies used for small electric drones was carried out in [18]. Rulebased EMSs are widely implemented in drones thanks to their simplicity and the possibility of real-time execution $[19,20]$. Zhang et al. [21] have experimentally investigated an online fuzzy rule-based EMS for a fuel cell/battery-based drone. The proposed strategy presented a low hydrogen consumption comparatively to state machine and passive control strategies. However, the drone load power specificity was not considered in that study, as only a pulsed-power profile was implemented for the load. It should be mentioned that many researchers have assumed their own power profiles to simulate the requested power during the flight mission due to the difficulty to get real data [22].

One of the biggest challenges for small electric drones is their limited endurance which is their main performance parameter. Thus, many researchers and drone companies are focusing on this issue trying to increase their flight time. Several studies were carried out by studying different aspects for long endurance fuel cell powered drones, such as energy-based conceptual design [23], thermal efficiency analysis [24], and hydrogen generation improvement [25]. Fuel saving is one of the solutions to extend the autonomy in all fuel cell-based mobile applications such as hybrid electric vehicles [26]. Some researchers have investigated fuel economy to optimize fuel cell hybrid systems using real-time and optimized control for the fueling regulators [27, 28, 29]. However, there is a lack of studies targeting drone applications. Akhtar et al. [30] studied the possibility of real-time trajectory generation based on the dynamic soaring model to optimize the fuel consumption.

In this study, a fuel cell-based drone energy management strategy is investigated targeting hydrogen consumption optimization. The commercialized DJI M100 quadcopter powered with the Intelligent Energy 650W fuel cell power module is considered as the case study [17]. This power module is in fact controlled through a simple rule-based EMS. In this context, a frequency separation rule-based power management strategy is proposed as a first improvement. Then, equivalent consumption minimization strategy (ECMS) is implemented intending hydrogen economy. Real data are implemented for the load power demand after carrying out a real flight test using an electric hexacopter.

\section{Drone Hybrid Power Supply System Topology}

In the literature, different topologies are proposed for integrating an energy storage system (battery, supercapacitor, or both) to the fuel cell-based power supply system. The choice of the appropriate architecture for our drone platform is important and necessary to optimize the overall system efficiency, weight, and cost. A comparison between active and passive topologies is carried out in [18]. Passive topology, in which power sources are directly connected to the DC bus, has the advantages of simplicity and high efficiency. Indeed and as example, in the Hyundai Nexo (2018) and Tucson ix35 (2014) fuel cell electric vehicles, fuel cell is directly linked to the DC bus [31]. However, this topology lacks power controllability, thus resulting in oversized fuel cell stack and reduced power density. In recent vehicles, the topology has been improved by integrating a DC boost converter between DC bus and fuel cell stack to increase its output voltage that consequently improves motor torque [31]. Therefore, in this paper, we will consider only active topologies for realizing an effective power/energy management strategy implementation.

The fuel cell is considered as the primary power source, its power output value should be controlled by the energy management system. Then, it is connected through a DC/DC boost converter to control its current flow. In addition, we should avoid to connect the fuel cell directly to the DC bus due to its output voltage high fluctuations. The battery operates as an energy buffer, and can be directly linked to the DC bus without any DC/DC converter reducing the system weight and power conversion losses. However, in that case the battery charging/discharging current cannot be managed, while overdischarging or overcharging might take place at any time due to power request peaks reducing the battery lifetime. In addition, the battery should be oversized in order to match DC bus voltage. Therefore, a bidirectional DC/DC converter is necessary to overcome these drawbacks and to insure the DC bus voltage regulation. The selected topology for the studied system is depicted in Fig. 1.

These converters with controllable switches enable us to actively implement several power allocation strategies. In case of frequency separation method, the fuel cell is assigned to deliver low frequency or steady state load power, and to charge the battery when needed. Higher frequency components will be supplied by the battery which is also controlling the DC bus voltage.

\subsection{Flight test}

In our study, an experimental flight test was carried out using a small battery-powered Y6 hexacopter from 3D Robotics company in order to extract a real load power profile. As shown in Fig. 2a, the drone has three arms in Y-shape with two counterrotating propellers for each arm to provide lift, acceleration, and 


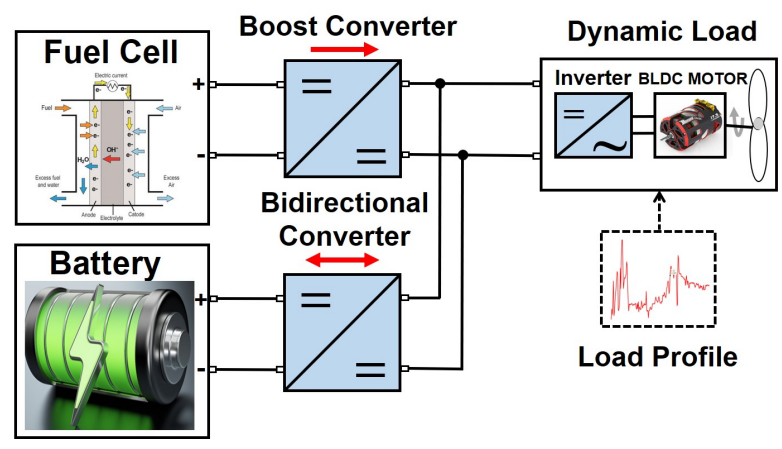

Figure 1: Hybrid power supply system topology.

stability. Table 1 presents the drone specifications and features [32]. To interface the drone with the ground control system, the "APM Planner 2.0" software is used. It is an open-source ground station application for management and control of the autopilot (Pixhawk) based on the MavLink (Micro Air Vehicle Link) protocol. It can be executed on Windows, Linux, and Mac OSX. The MavLink is a communication protocol for small multirotors. It enables real-time data monitoring such as battery output voltage and current. Furthermore, it is possible to get the real position through the GPS module mounted on board. In the "Flight Plan" section we can plan a flight mission that can be autonomously performed by the drone. With the help of a micro SD mounted on board, the Pixhawk is able to record all data and transmit them via radio to the ground station. Once the extension file (bin) has been obtained, it is necessary to convert it into the $\log$ extension to make it readable with Excel. It is worth noting that data are sampled with a frequency of $50 \mathrm{~Hz}$ according to the acquisition card. However, 1 sec-averaged data are stored in the log file.

In order to gather data with a good accuracy and to ensure flight safety, it is necessary to calibrate the sensors particularly accelerometers, compass, radio control, power module, and the electronic speed controller (ESC).

Table 1: 3D Robotics Y6 hexacopter specifications.

\begin{tabular}{|c|c|c|}
\hline \multirow{7}{*}{ Airframe } & Weight (with battery) & $1905 \mathrm{~g}$ \\
\hline & Motors & $850 \mathrm{KV}$ brushless motors \\
\hline & Propellers & $10 \times 4.7$ slow-fly APC \\
\hline & Electronic Speed & SimonK firmware $(20 A)$ \\
\hline & Controller (ESC) & 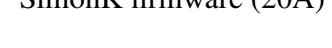 \\
\hline & Payload capacity & $600 \mathrm{~g}$ \\
\hline & Average Autonomy & $12-15 \min$ \\
\hline \multirow{4}{*}{ Battery } & Type & Lipo $14.8 \mathrm{~V}$ \\
\hline & Weight & $602 \mathrm{~g}$ \\
\hline & Capacity & $\mathrm{mAh}$ \\
\hline & Maximum power & $1135 \mathrm{~W}$ \\
\hline \multirow{3}{*}{ Features } & \multicolumn{2}{|c|}{ Pixhawk autopilot system with GPS navigation } \\
\hline & \multicolumn{2}{|c|}{ Remote control (Spektrum dx7s) } \\
\hline & \multicolumn{2}{|c|}{$\begin{array}{l}\text { Autonomous flight modes, waypoint navigation, loi- } \\
\text { ter, circle, and return to launch }\end{array}$} \\
\hline
\end{tabular}

The test was conducted in Salento university campus in Italy [33] (Fig. 2b). The load power curve consists of the battery de- livered power during the mission, including take-off maneuver and hovering operation (Fig. 3). The other power request profiles for larger multicopters can also be estimated by assuming the proportionality between load power and drone weight with a 3/2 factor [34]. Table 2 presents the obtained power profile characteristics. To get a larger mission lifetime and to solicit even more our power supply system, the load profile is repeated several times replicating the hovering phase and extending the flight test duration to $42 \mathrm{~min}$ as depicted in Fig. 4.

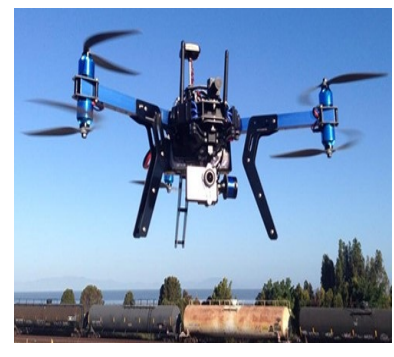

(a)

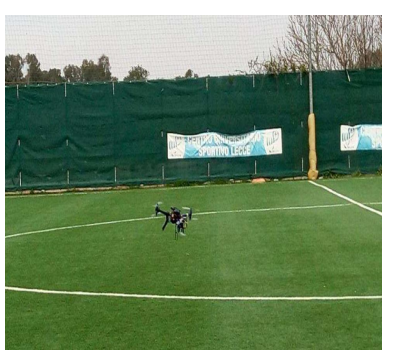

(b)
Figure 2: (a) 3D Robotics Y6 hexacopter [32] and (b) the Y6 drone in take-off phase.

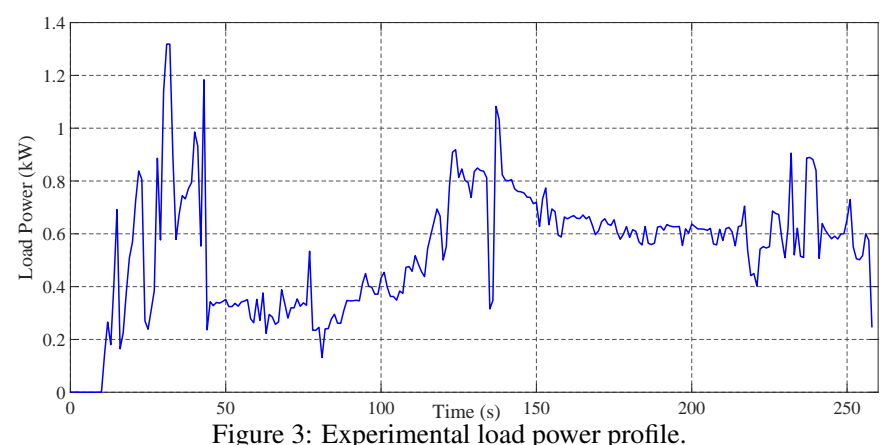

Table 2: Power profile characteristics.

\begin{tabular}{lr}
\hline Profile characteristics & Value \\
\hline Duration & $260 \mathrm{~s}$ \\
\hline Average power & $544 \mathrm{~W}$ \\
\hline Maximum power & $1319 \mathrm{~W}$ \\
\hline Transient peak power & $+741 \mathrm{~W} \mathrm{(2s)}$ \\
& $-696 \mathrm{~W}(3 \mathrm{~s})$ \\
\hline
\end{tabular}

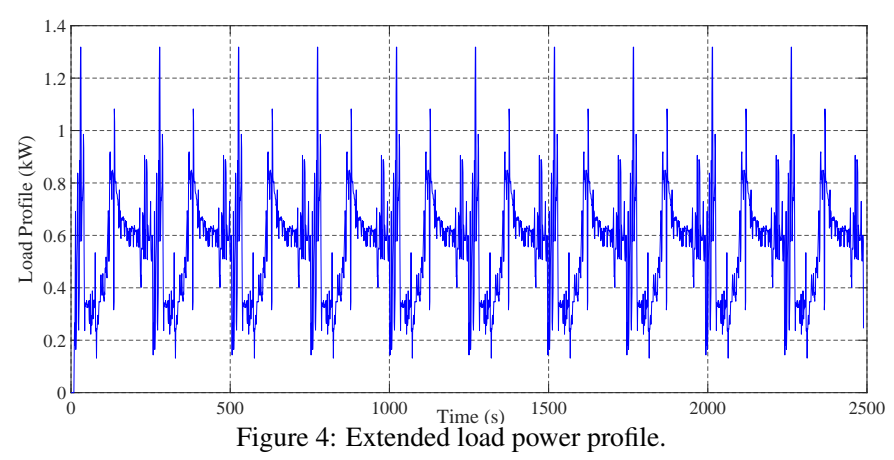

\subsection{Case study}

Several international companies are investing on fuel cell powered drones and among them Ballard, Intelligent Energy, HES Energy Systems, H3 Dynamics, MicroMultiCopter, etc. 
Intelligent Energy is a fuel cell engineering company working on the development and commercialization of its lightweight Proton Exchange Membrane (PEM) fuel cell for drone applications extending the flight time and bypassing the limitations of batteries. In this study, we have chosen the DJI M100 quadcopter powered by their $650 \mathrm{~W}$ fuel cell as depicted in Fig. 5. The fuel cell power module specifications exploited in this study are listed in Table 3.

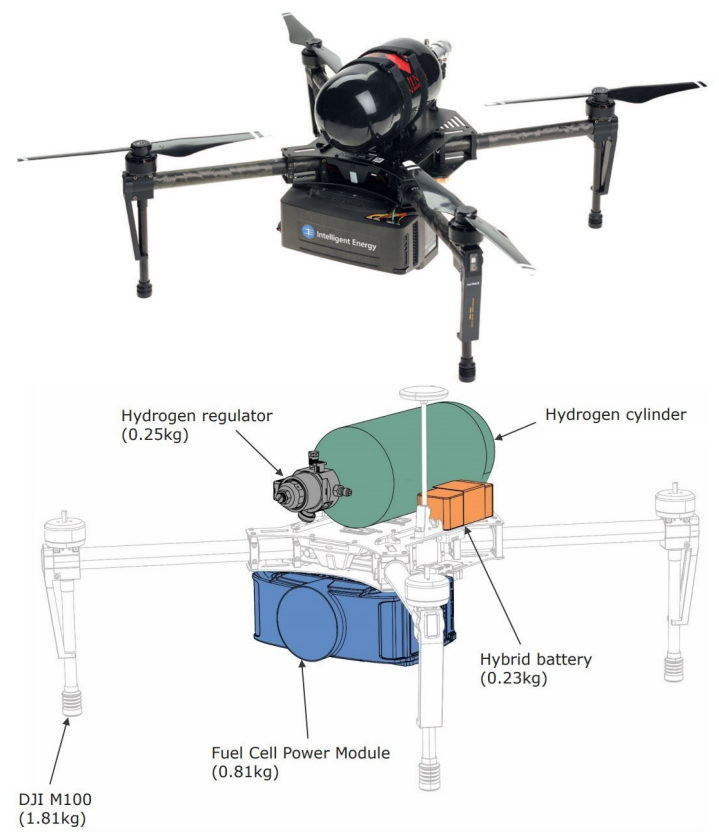

Figure 5: DJI M100 quadcopter with Intelligent Energy 650W fuel cell power module [17].

Table 3: Intelligent Energy 650W fuel cell power module specifications [17].

\begin{tabular}{|c|c|c|}
\hline \multirow{5}{*}{ Fuel cell } & Maximum continuous power & $650 \mathrm{~W}$ \\
\hline & Maximum peak power & $1000 \mathrm{~W}$ \\
\hline & Output voltage & $29.6-25.2 \mathrm{~V}$ \\
\hline & Weight & $810 \mathrm{~g}$ \\
\hline & Sizes & $196 \times 88 \times 140 \mathrm{~mm}$ \\
\hline \multirow{4}{*}{$\begin{array}{l}\text { Hydrogen } \\
\text { regulator }\end{array}$} & Weight & $250 \mathrm{~g}$ \\
\hline & Maximum pressure & 300bar \\
\hline & Output pressure & $0.5 \mathrm{bar} \pm 0.25 \mathrm{bar}$ \\
\hline & Maximum tank weight & $10 \mathrm{~kg}$ \\
\hline \multirow{4}{*}{ Battery } & Capacity & $1300 \mathrm{~mA} \mathrm{~h}$ \\
\hline & Weight & $230 \mathrm{~g}$ \\
\hline & Sizes & $140 \times 30 \times 20 \mathrm{~mm}$ \\
\hline & Emergency flight time & $2 \mathrm{~min}$ \\
\hline \multirow{2}{*}{ Features } & \multicolumn{2}{|c|}{ Automatic failure detection and backup battery } \\
\hline & \multicolumn{2}{|c|}{$\begin{array}{l}\text { Data storage for firmware update, performance, and } \\
\text { diagnostics }\end{array}$} \\
\hline
\end{tabular}

\section{Energy Management Strategy}

In this paper, three energy management strategies are proposed and compared, namely, basic rule-base strategy (RBEMS), frequency separation rule-based strategy (FSRB-EMS), and equivalent consumption minimization strategy (ECMS).

\subsection{Rule-based strategy (RB-EMS)}

The energy management strategy used for the Intelligent Energy fuel cell power module is based on if-then rules. As shown in Fig. 6, the fuel cell continuously supplies a rated power, which corresponds to the hovering necessary power (800W) regardless of the load power variations. The battery will either supply the extra needed power (especially peaks) or be charged when the fuel cell rated power exceeds the load power. Indeed, this simple method has many disadvantages. The hovering power is not always fixed because it depends on many factors such as the payload, the type of mission, and even weather conditions. The fuel cell rated power does not necessarily match the hovering power, consequently it will operate outside of its high-performing operational zone, and even the battery can be solicited to deliver high current to supply the extra needed power. Thus, both sources will undergo rapid degradation and decrease of their lifetimes. In addition, the drone is supposed to conduct different type of missions, not only hovering-based missions, the EMS has then to be adapted. It is worth noting that a best situation has been considered for the implementation of RB-EMS, when the nominal power match the hovering power, which is not always the case.

Therefore, in this work, two alternative EMSs have been proposed for the considered drone. Firstly, the frequency separation rule-based strategy which aims to keep the fuel cell operating in high efficiency areas areas irrespective of the mission conditions, thus preserving its lifetime. Secondly, the ECMS which aims to optimize the hydrogen consumption during the flight mission for extending the drone autonomy.

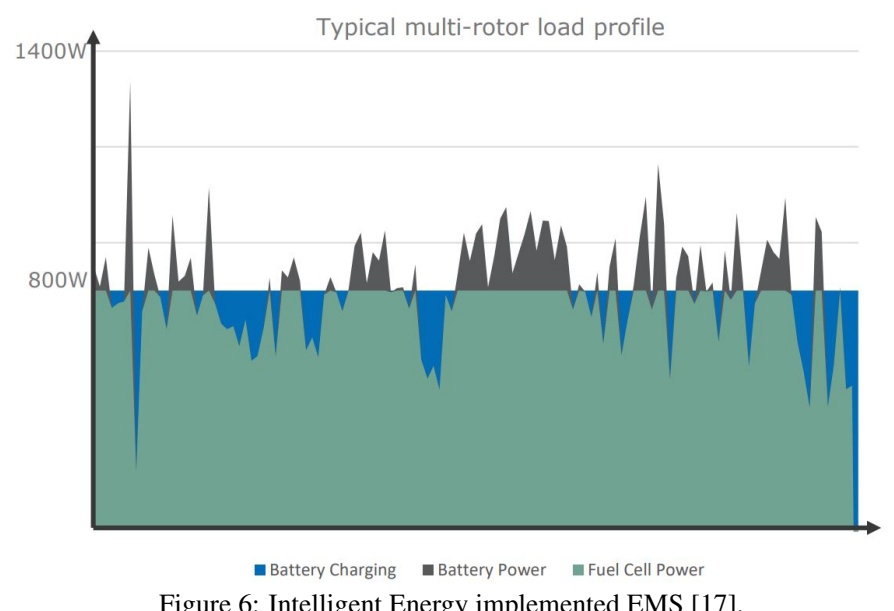

\subsection{Frequency separation rule-based strategy (FSRB-EMS)}

This method is an improved version of the frequency separation strategy. In this context, the power splitting is based on the load power frequency decomposition assigning to the fuel cell 
only low frequency components. Thus, the fuel cell lifetime will be improved by avoiding power fluctuations [35]. However, the energy storage system lifetime is still neglected. The battery state of charge (SOC) and charge/discharge current are not supervised, which results in undergoing high stress thus decreasing its performances. In addition, for security reasons, it is required to keep a minimum threshold of battery energy during the flight. Such security measure is necessary for the battery to provide enough energy for emergency drone landing in case of damage or failure of fuel cell system or DC/DC boost converter.

For the fuel cell, even though its supplied power profile will be smooth, the strategy can not guarantee efficient operation. A minimum/maximum sustainable output power, which is indicated by the manufacturer, must be taken into consideration. Operating below/above these limits for a long time causes problems such as clogging and cooling [36]. Therefore, combining frequency separation with a rule-based strategy is proposed as a solution to overcome these limitations. The battery SOC can thus be maintained in an acceptable range while the fuel cell will operate in nominal conditions with high efficiency.

The following thresholds or criteria must be defined: maximal battery SOC $\left(S O C_{\max }\right)$, minimal battery SOC $\left(S O C_{\min }\right)$, the charging power $\left(P_{\text {char }}\right)$ to charge the battery when needed, maximal fuel cell output power $\left(P_{F C-\max }\right)$, optimal fuel cell output power $\left(P_{F C-o p t}\right)$, and minimal fuel cell output power $\left(P_{F C-m i n}\right)$. The battery SOC and the load power $\left(P_{\text {Load }}\right)$ are chosen as decision variables. According to these two variables values, the fuel cell output power reference $\left(P_{F C}^{*}\right)$ is calculated and supplied through the DC/DC boost converter as shown in Fig. 7a. The remaining demand power $\left(P_{\text {Load }}-P_{F C}^{*}\right)$ will be supplied by the energy storage system. The DC bus voltage $V_{B u s}$ regulation scheme is depicted in Fig. $7 \mathrm{~b}$, where $V_{D C-r e f}$ is the reference and $D$ is the duty cycle used to control the bi-directional DC/DC converter.

The control rules defined by the EMS are illustrated in Fig. 8 considering the two decision variables $S O C$ and $P_{\text {Load }}$. In order to increase the operation efficiency, $P_{F C}^{*}$ is assigned equal to $P_{F C-o p t}$ when $P_{\text {Load }}$ is between $P_{F C-\min }$ and $P_{F C-o p t} . P_{F C}^{*}$ is bounded when $P_{\text {Load }}$ falls below $P_{F C-\min }$ or exceeds $P_{F C-\max }$. If the battery is fully charged, the fuel cell will just follow the load demand.

\section{3. $E C M S$}

The focus of this work is to extend the drone autonomy, for which an optimal EMS has to be implemented as FSRB-EMS is unable to achieve this goal. The strategy aims to reduce the hydrogen consumption, thereby increasing the drone operating time. Global optimization algorithms are well developed in the electric vehicle field such as dynamic programming [37], genetic algorithm [38], particle swarm optimization [39]. However, a global optimization usually requires a priori driving cycle to find global optimization results. In addition, it is timeconsuming and complex, and it can not be implemented in real time. Unlike electric vehicles, weight and computational effort are very important constraints in electric drones. Thus, local optimization algorithms are the appropriate alternatives for our

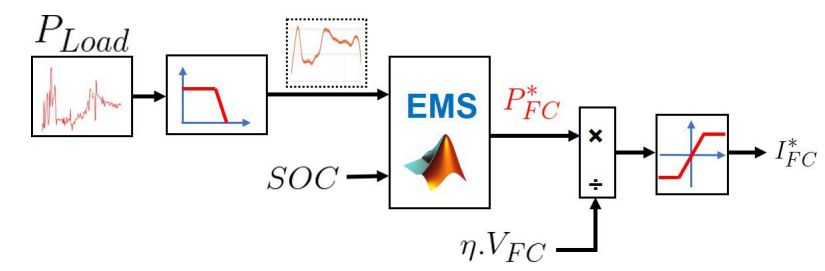

(a)

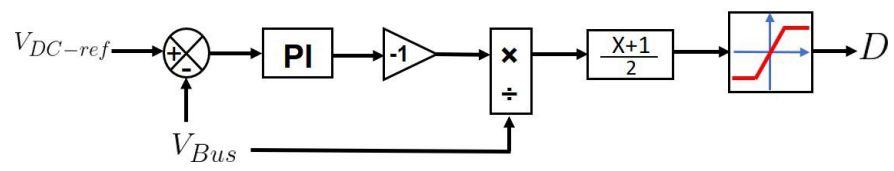

(b)

Figure 7: (a) Energy management scheme and (b) DC bus voltage control scheme.

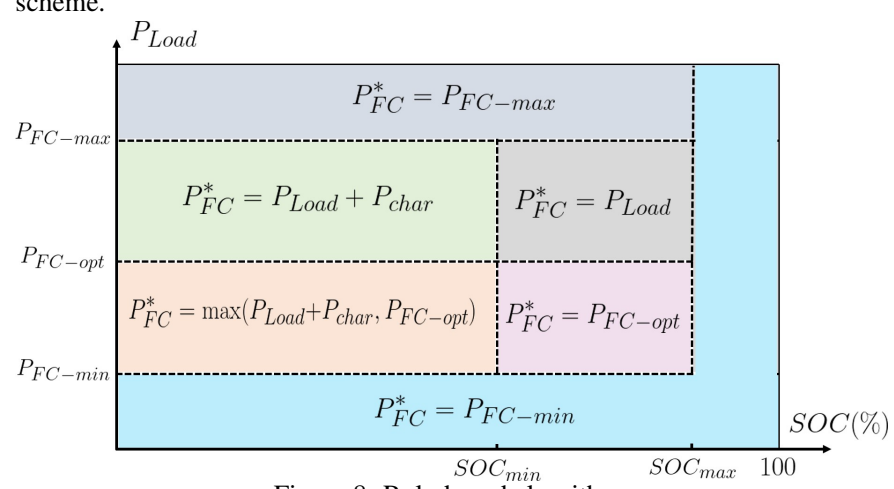

Figure 8: Rule-based algorithm.

application. The optimization period is reduced from the complete driving cycle to an instantaneous sample time to calculate the optimal control variables.

In this context, ECMS is proposed. Indeed, it is investigated in the literature for mobile applications such as electric/hybrid vehicles [40, 41] and tram [42, 43]. The concept of ECMS is to minimize the sum of hydrogen directly consumed by the fuel cell, and the amount used indirectly by the energy storage sources (equivalent consumption) at each sampling time while insuring effective operating for each source. In this way, it does not need future prediction or a priori data about the scheduled mission. When the battery provides energy, its SOC will decrease, so the fuel cell has to supply the needed energy to recharge it by consuming hydrogen. When the battery SOC is high, its energy will be used for future maneuvers such as climbing or accelerations leading to a reduction in hydrogen consumption [44]. Thus, the battery delivered energy is converted to an equivalent hydrogen consumption to have a singleobjective minimization problem.

The battery virtual hydrogen consumption is proportional to its energy multiplied by an equivalence factor $\lambda$. It depends on the battery SOC and can be expressed empirically as [42]

$$
\lambda=1-2 \beta\left[\frac{S O C-0.5\left(S O C_{\max }+S O C_{\min }\right)}{S O C_{\max }+S O C_{\min }}\right]
$$

where $\beta$ is the SOC balance coefficient. It is used for accurately representing the charge/discharge processes (chosen equal to 


\subsection{5 in [42] and 0.6 in [45]).}

The equivalence factor is the most important parameter in ECMS. The larger it is, the more the battery energy is penalized and consequently the hydrogen consumption increases to recharge the battery. On the contrary, if it is too small, the fuel cell energy is penalized and the algorithm will calculate the power references to use more energy from the battery for adjusting its SOC back to its permitted range. The equivalence factor $\lambda$ is considered in the cost-function in order to make the ECMS algorithm less dependent to the balance coefficient $\beta$. The problem formulation can be as follows. Calculate the optimal solution $y=\left[P_{F C}, \lambda, P_{B a t}\right]$, which minimizes

$$
F=\left[P_{F C}+\lambda \cdot P_{B a t}\right] . \Delta T
$$

subject to

$$
\left\{\begin{array}{c}
P_{\text {Load }}=P_{F C}+P_{\text {Bat }} \\
P_{F C-\text { min }} \leqslant P_{F C} \leqslant P_{F C-\text { max }} \\
P_{\text {Bat-min }} \leqslant P_{\text {Bat }} \leqslant P_{F B a t-\text { max }} \\
0 \leqslant \lambda \leqslant 2
\end{array}\right.
$$

where $P_{B a t-\max }$ and $P_{B a t-\min }$ are the maximum and minimum battery powers, respectively. To solve the optimization problem under Matlab/Simulink, "fmincon" function. This function uses a sequential quadratic programming (SQP) method to solve a subproblem at each iteration. $y=$ $\operatorname{fmincon}\left(F, y_{0}, A, B, A_{e q}, B_{e q}, L B, U B, O P T I O N S\right)$ starts at $y_{0}$ and tries to find a minimizer $y$ of the objective function $F$. $A$ and $B$ are used for describing linear inequalities $(A . y \leqslant B)$, for our case $A=B=$ [] (empty matrix). $A_{e q}$ and $B_{e q}$ define the linear equalities $\left(A_{e q} . y=B_{e q}\right) . U B$ and $L B$ define the upper and lower bounds of the solution $(L B \leqslant y \leqslant U B)$. OPTIONS is an argument created with the OPTIMOPTIONS function which allows to set the optimization parameters such as maximum iterations (set to 100) and maximum function evaluations (set to 1000). For the case study, we have

$$
\begin{gathered}
y_{0}=\left[P_{F C-\min }, 0,0\right] ; \quad A_{e q}=\left[\begin{array}{lll}
0 & 1 & 0 \\
1 & 0 & 1
\end{array}\right] \\
B_{e q}=\left[\begin{array}{c}
1-2 \beta\left[\frac{S O C-0.5\left(S O C_{\max }+S O C_{\min }\right)}{S O C_{\max }+S O C_{\min }}\right] \\
P_{\text {Load }}
\end{array}\right] \\
U B=\left[\begin{array}{c}
P_{F C-\max } \\
2 \\
P_{\text {Bat-max }}
\end{array}\right] ; \quad L B=\left[\begin{array}{c}
P_{F C-\min } \\
0 \\
P_{\text {Bat-min }}
\end{array}\right]
\end{gathered}
$$

\section{Hybrid Power System Modeling}

Fuel cell and battery modeling literature presents different approaches, namely, empirical [46], electro-chemical [47], and electric-circuit based modeling [48]. Empirical models are based on look-up tables or curve fitting using experimental data such as charge/discharge and polarization curves. When parameters match with an already identified case, the outputs fit exactly the measured data. Otherwise, an error will occur. This approach is simple, but the model will be restricted to the studied power source and cannot be generalized. Electrochemical models are based on electro-chemical and thermodynamics equations, which include several sub-components such as electrode and catalyst layer. They are primarily used for design purposes representing the power source dynamic behavior and thermodynamic phenomena. However, they require specific parameters real data as electrolyte volume and electrode thickness, which are not easily available. In addition, it is worth mentioning that both previous approaches do not take into account battery SOC dynamics. Electric circuit-based modeling involves use of ideal electrical elements to represent power sources characteristics such as ohmic losses, open circuit voltage, and capacity. Experimental tests, as impedance spectroscopy and current interrupt, or frequency response, should be conducted to identify these parameters [49]. Although these models represent electrical properties, they are operating conditions-dependent.

In this paper, the adopted approach was developed in [49] and the obtained generic model is available in Simulink/SimPowerSystems (SPS). The method consists in a combination between curve fitting characteristics and electric circuit-based models. This model is appropriate to electrical simulations and its parameters can easily be derived from the manufacturer datasheet.

The hybrid energy system is simulated under Matlab/Simulik using the predefined generic models available in SimPowerSystems toolbox for power and energy sources. Model parameters are extracted from the Intelligent Energy 650W fuel cell power module specifications already listed in Table 3. For DC/DC converters, average value models are adopted and implemented.

\subsection{Fuel cell model}

PEM fuel cells are widely used for drones due to their good features such as fast starting and low operating temperature reducing the warm-up time, thus fast response can be achieved. The selected model is developed in [49]. The fuel cell output voltage $V_{f c}$ is given by

$$
V_{f c}=E_{O C}-V_{a c t}-V_{O h m}
$$

with

$$
\begin{gathered}
V_{a c t}=A \cdot \ln \left(i_{f c} / i_{0}\right) \cdot \frac{1}{1+s \cdot T_{d} / 3} \\
V_{O h m}=r_{O h m} \cdot i_{f c}
\end{gathered}
$$

where $E_{O C}$ is the open circuit voltage $(\mathrm{V})$ and it is determined by the chemical thermodynamics of the overall cell reaction. $V_{a c t}$ is the activation voltage drop and it is due to the slowness of the reactions on the electrode surface. $V_{O h m}$ represents the ohmic losses due to the resistance to the flow of electrons through the cell hardware and various interconnections, and ions in the electrolyte. $A$ is called Tafel slope $(\mathrm{V})$, and $i_{0}$ is 
the exchange current (A). Indeed, the cell voltage cannot track current changes instantaneously. The voltage response delay to a current variation, which is caused by the charge double layer phenomenon, is represented by $T_{d}$ as shown in Fig. 9. A diode is used to prevent any eventual reverse current flow. Normally, the boost converter plays that role when connected to the stack.

Under nominal operating conditions, only four points from the polarization curves are needed to determine the model parameters. However, if the operating conditions such as pressure, temperature, air and fuel flow rates are variable, parameters $\left(E_{O C}, A, i_{0}\right)$ are updated.

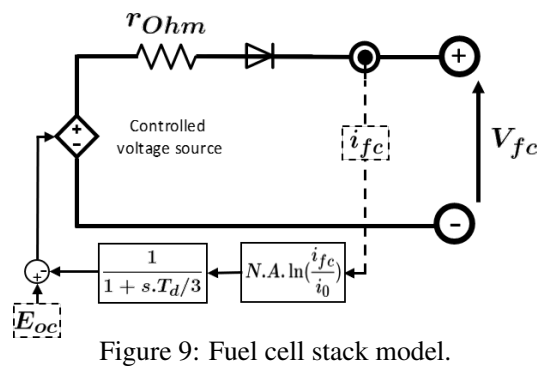

\subsection{Battery model}

A Li-ion battery type is adopted in this study since it is characterized by high energy density and efficiency relatively to other battery types. Hence, it is a suitable battery type for drones applications. The adopted model is based on an updated Shepherd curve fitting model where a voltage polarization term is included to represent battery SOC effect. In addition, to guarantee simulation stability, a filtered battery current $\left(i^{*}\right)$ is used to calculate the polarization resistance Pol $_{\text {res }}$. The battery voltage can be written as [50]

$$
V_{b a t}=E_{0}-R_{\text {int }} . i-K \frac{Q}{Q-i t} . i t-K \frac{Q}{Q-i t} \cdot i^{*}+A \cdot \exp (-B . i t)
$$

where $E_{0}$ represents the battery constant voltage (V) and $R_{\text {int }}$ is the internal resistance. $Q$ and $i t=\int i . d t$ refer to the battery capacity and actual charge $(\mathrm{Ah})$, respectively. The polarization constant is represented by $K(\mathrm{~V} / \mathrm{Ah})$, and $B$ is the time constant for the exponential area $(\mathrm{Ah})^{-1}$. The polarization resistance Pol $_{\text {res }}$ is represented by the term $K \frac{Q}{Q-i t}$, while the polarization voltage is represented by the term $K \frac{Q}{Q-i t} . i t$. As in the fuel cell case, the model parameters can be set using the manufacturer datasheet or by conducting a polarization test. The model equivalent circuit is shown in Fig. 10.

\section{3. $D C / D C$ converters models}

Different DC/DC converters topologies are proposed in the literature, they can be either isolated or non-isolated converters. The former are mainly used in medium and low power applications and they are characterized by high voltage ratio and galvanic isolation [31]. The latter have a simple architecture and they are compact, but they provide low voltage ratio. In [51], several DC/DC converters architectures are compared and evaluated considering different criteria such as reliability, effectiveness, losses, and cost.

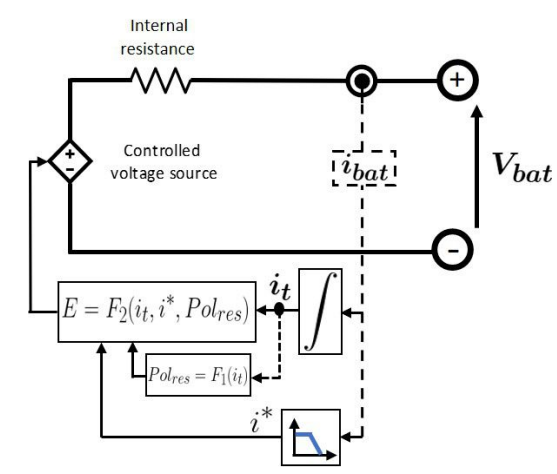

Figure 10: Battery model.

DC/DC converters can be implemented using either average value models or switching models. The second type enables monitoring all the switching phenomena. However, it requires high sampling frequency and consequently a large simulation time, and they are dedicated to design studies. Then, average value models are adopted and implemented using controlled current/voltage sources to replace switches. The conversion dynamics are maintained and the simulation time is highly decreased. The implemented average value models and their standard switching models are depicted in Figs. 11 and 12 where $V_{H}$ and $V_{2}$ come from DC bus side, $\eta$ is the converter efficiency, and $D$ is the duty cycle.

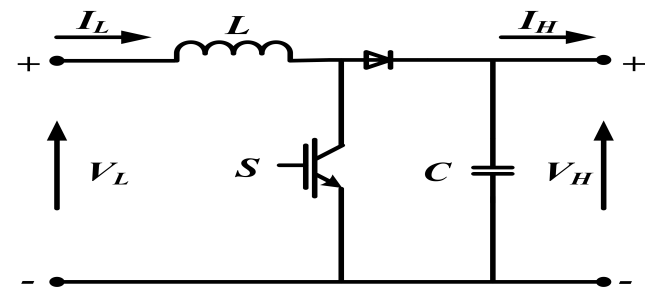

(a)

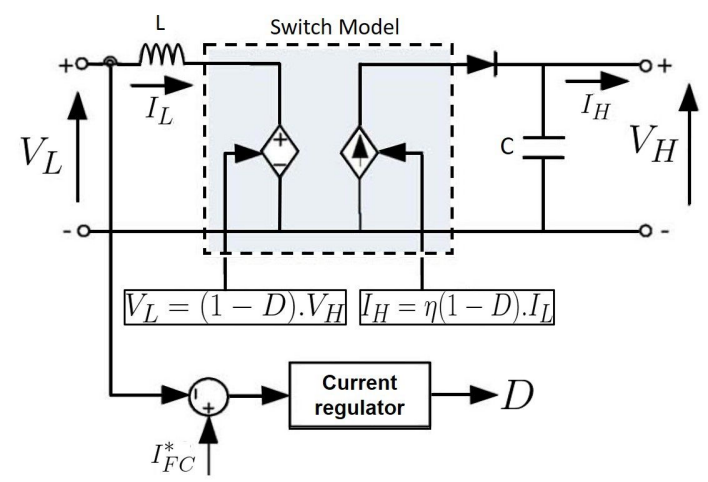

(b)

Figure 11: DC/DC boost converter. (a) Switching model, (b) average value model.

\section{Simulation Results and Discussion}

The three energy management strategies are implemented in Simulink using SimPowerSystems toolbox. To achieve a feasible comparison, same conditions are set for all strategies (load power requirement, sources characteristics, initial SOC (70\%), DC bus, and DC/DC converters control parameters). 


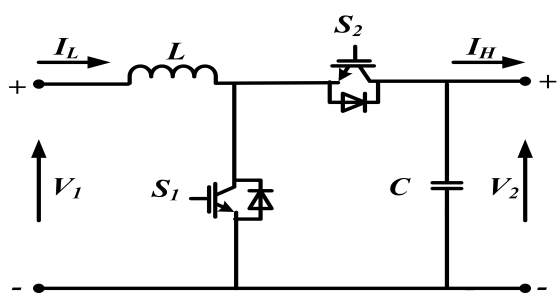

(a)

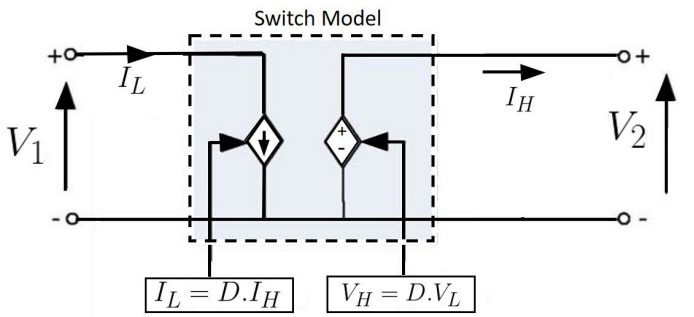

(b)

Figure 12: DC/DC bidirectional converter. (a) Switching model, (b) average value model.

\subsection{Power distribution}

Figure 13 shows the fuel cell and battery delivered powers for each EMS considering converter losses. In the RB-EMS (Fig. 13a) the fuel cell is delivering constant power, the battery provides the extra needed power, especially the peaks, to match the desired load power. When the load power is less than the fuel cell one, the battery starts charging for increasing its SOC. The fuel cell and battery act then as energy and power sources, respectively, with a relatively short response time for the battery. For FSRB-EMS in Fig. 13b, it is observed that the fuel cell power follows well the energy management strategy rules. It supplies power according to the pre-defined operating points $\left(P_{F C-\min }\right.$ and $\left.P_{o p t}\right)$. Outside these points, the fuel cell either supplies the needed extra power to charge the battery when its SOC is low or follow the load power when the SOC is high. For the ECMS in Fig. 13c, the power profile is slightly more fluctuating due to the optimization algorithm, which tries, for each sample time, to find out the good reference that minimizes the hydrogen consumption.

\subsection{SOC and DC bus voltage}

The SOC and DC Bus voltage results are depicted in Fig. 14. Figure 14a highlights one of the biggest drawback of RBEMS. The SOC average is continuously increasing because the battery is receiving power more than the delivered one. In this context, there is high possibility that the battery will be overcharged during the mission. This issue is due to the fact that fuel cell reference power is not adapted to SOC variations. On contrary, for the RBFS-EMS (Fig. 14b), the calculated fuel cell reference is considering SOC and requested power regarding the fuel cell preferred operating points. When the SOC reach its maximum $\left(S O C_{\max }=90 \%\right)$, battery will be forced to discharge and less power will be demanded from the fuel cell. For the ECMS (Fig. 14c), the SOC is continuously decreasing in average, and stabilizes after the 7 th cycle respecting the condition $S O C_{\min }=60 \%$. The method is using battery energy as much as possible.

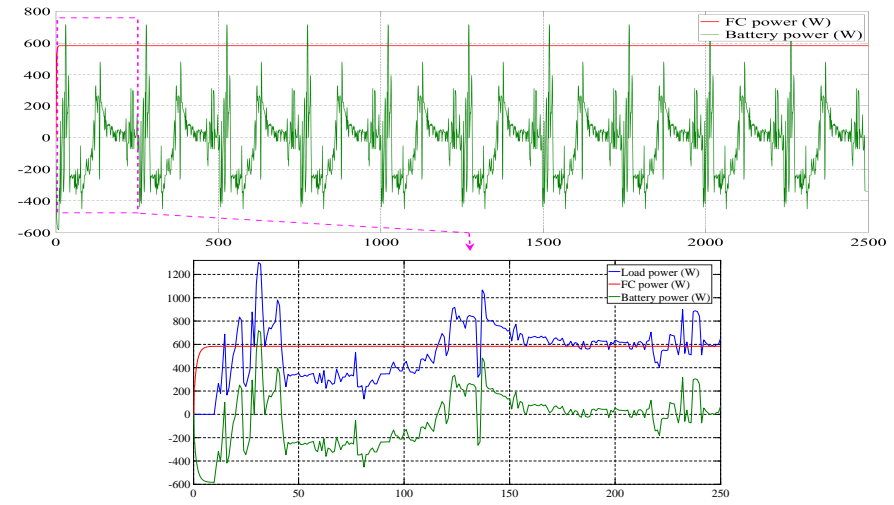

(a) RB-EMS

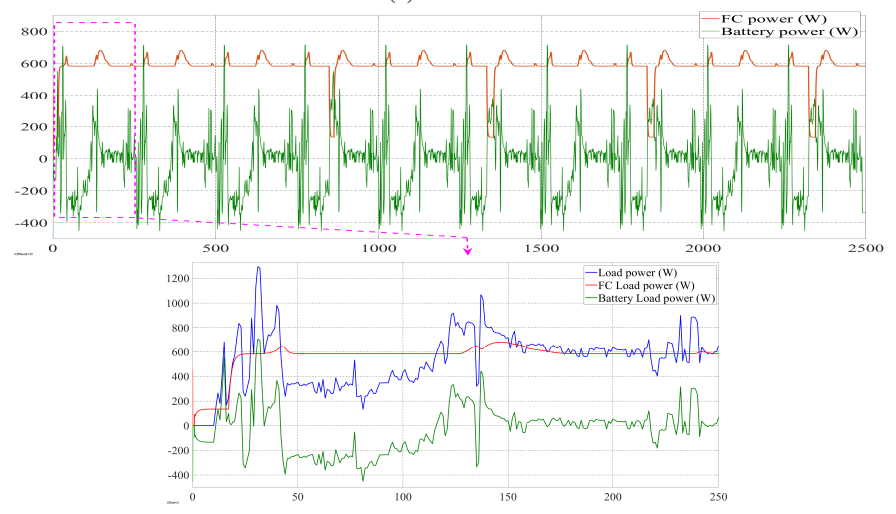

(b) FSRB-EMS

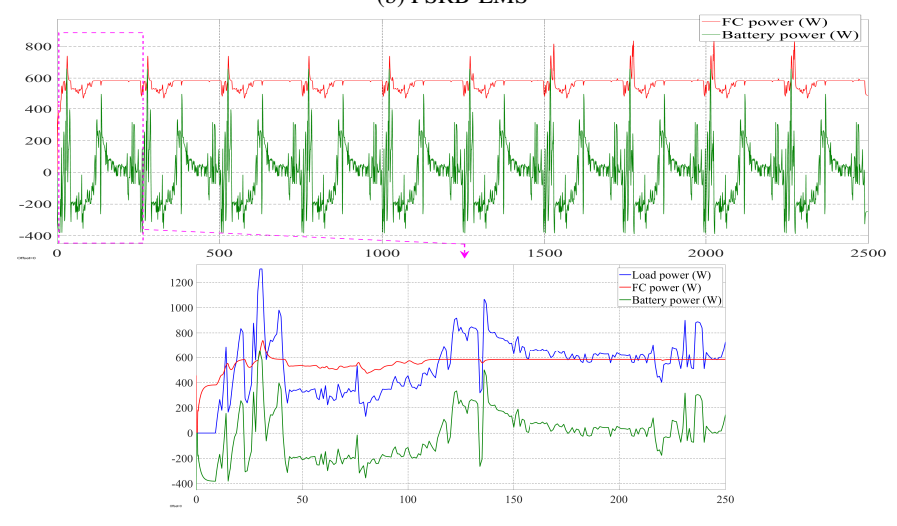

(c) ECMS

Figure 13: Power distribution simulation results.

The DC bus voltage is well regulated around the reference of $55 \mathrm{~V}$ similarly for the three strategies with relatively smaller peaks for ECMS.

\subsection{Current and voltage responses}

Figure 15 shows the power sources current and voltage responses during the mission. For the strategies, battery and fuel cell voltages are fluctuating around their nominal values $(24 \mathrm{~V}$ and $21.5 \mathrm{~V}$ respectively), and the delivered current does not exceed the permitted range. Thus, the power sources are operating within their nominal areas.

\subsection{Efficiency}

The overall efficiency $\eta$ is given by 


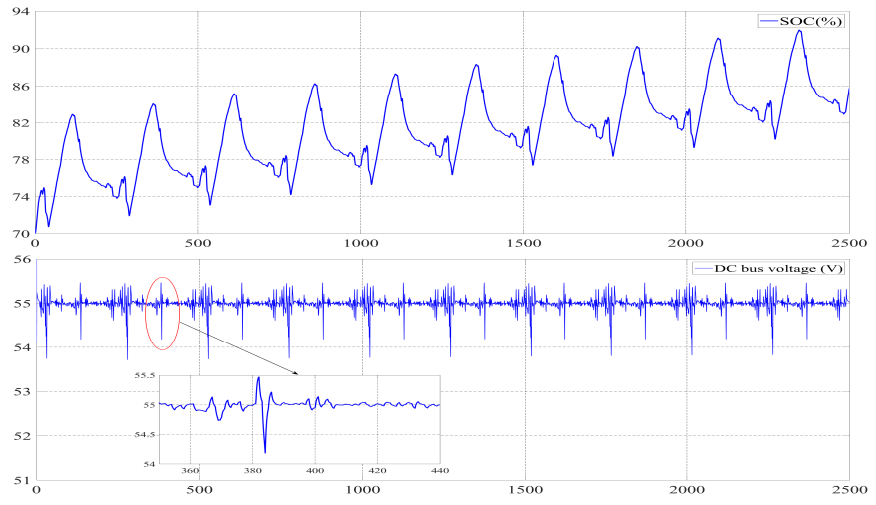

(a) RB-EMS

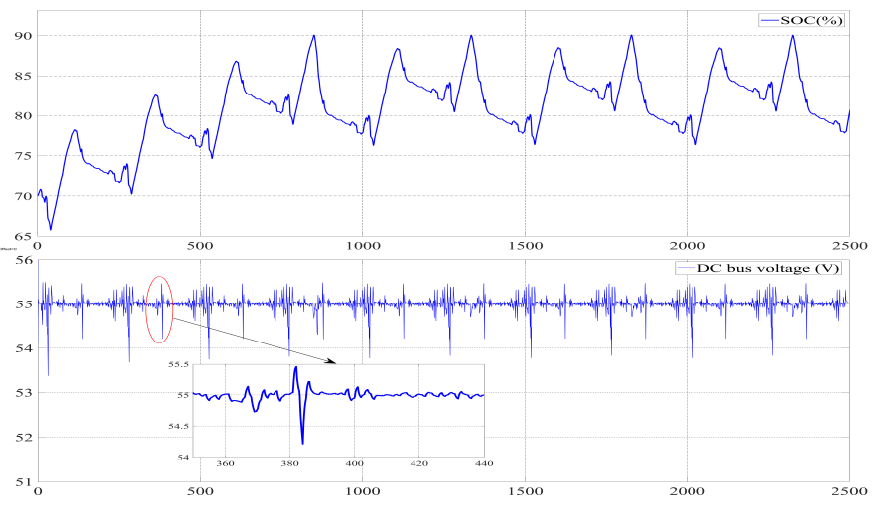

(b) FSRB-EMS

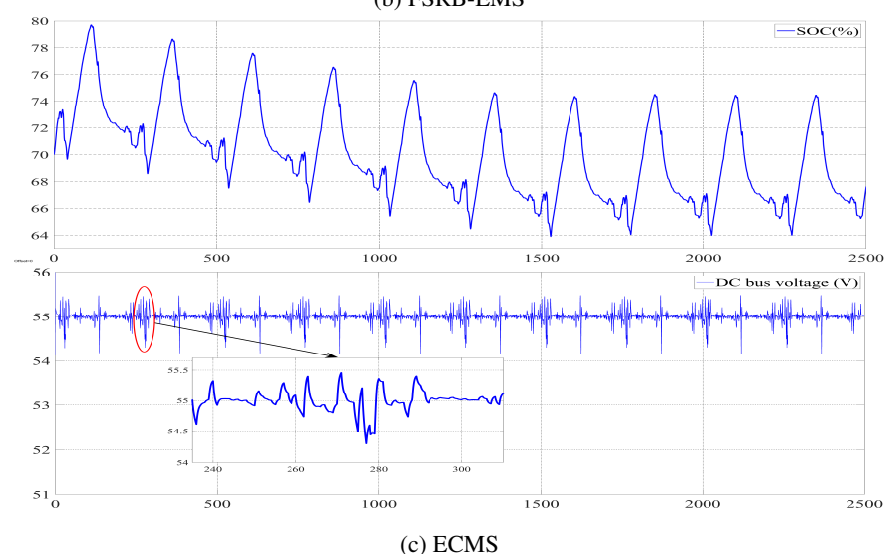

Figure 14: SOC and DC bus voltage simulation results.

$$
\eta=\frac{P_{\text {load }}}{P_{F C}+P_{\text {Bat }}}
$$

where $P_{F C}$ and $P_{B a t}$ are the fuel cell and battery delivered powers, respectively (input to DC/DC converters).

The efficiency average values for the three strategies are close (around 85\%) with a slight advantage for ECMS. The results are shown in Fig. 16.

\subsection{Hydrogen consumption}

The hydrogen consumption $\left(C_{H_{2}}\right)$ during the flight mission is calculated as follows

$$
C_{H_{2}}=\frac{N}{F} \int_{0}^{T_{f}} i_{f c} \cdot d t
$$

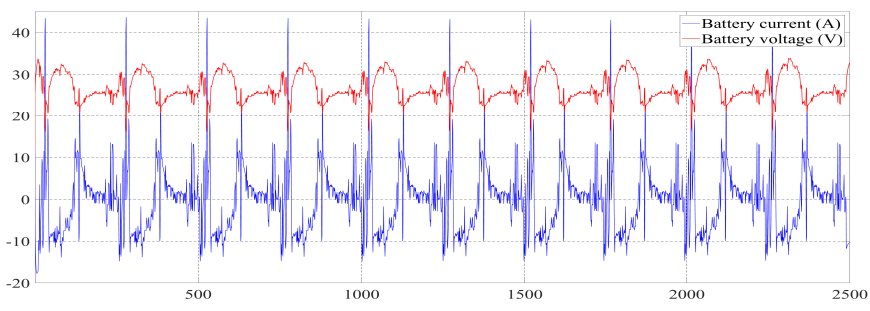

(a) RB-EMS

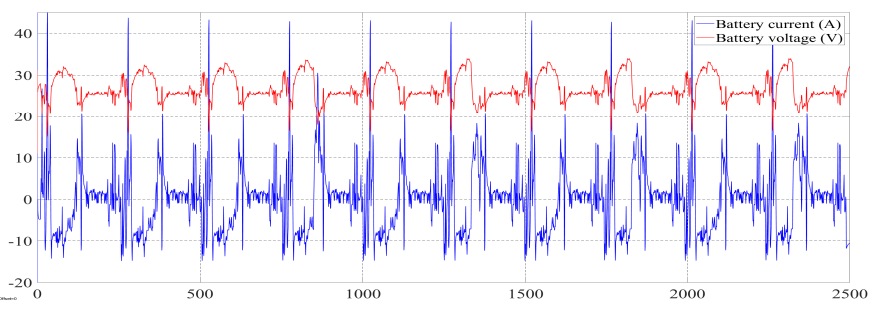

(b) FSRB-EMS

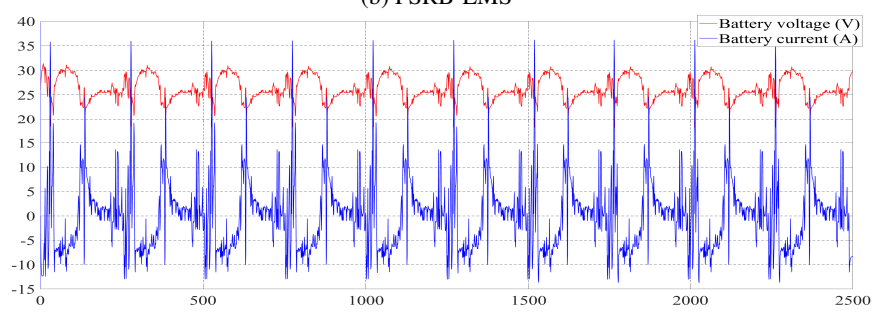

(c) ECMS

Figure 15: Current and voltage responses simulation results.

where $F$ is Faraday constant $\left(\mathrm{As} \mathrm{mol}^{-1}\right)$ and $T_{f}$ is the flight duration (s). Figure 16 illustrates the hydrogen consumption variation during the mission and Table 4 shows the overall hydrogen consumption (in $\mathrm{g}$ ) for each strategy. $C_{H_{2}}$ is similar for both RB-EMS and RBFS-EMS. However, the ECMS enables a $3 \%$ improvement.

Table 4: Total hydrogen consumption.

\begin{tabular}{cccc}
\hline EMS & RB & RBFS & ECMS \\
\hline Hydrogen consumption $(\mathrm{g})$ & 22.047 & 22.004 & 21.385 \\
\hline
\end{tabular}

\subsubsection{Hydrogen saving benefits}

To study fuel saving and its effect on the operating cost, a real scenario has been analyzed. In fact, there are a wide range of flight missions, and it is difficult to estimate hydrogen consumption. In this context, a study is carried out in [52] considering two types of drones: multicopter drone $(10-15 \mathrm{~kg})$ and fixed wing drone $(20-25 \mathrm{~kg})$ based on Aerostack and FCAir fuel cell systems (from HES and Ballard, respectively). The hydrogen consumption rate is estimated $79 \mathrm{~g} \mathrm{~h}^{-1}$ for the multirotor drone. The Ballard fuel cell stack lifetime is given by $3000 \mathrm{~h}$. Thus, the amount of saved hydrogen during one lifecycle by one drone is equal to $0.03 \times 79 \times 3000=7110 \mathrm{~g}$. The hydrogen cost when provided by an industrial gas supplier in Norway is $0.12 € \mathrm{~g}^{-1}$ [13]. Thus, the economical benefit is $853.2 €$ per drone during one fuel cell module lifetime. In a context of drone fleets, which the general case for many companies for specific missions such as delivery or inspection, the benefit will be multiplied by the number of deployed drones.

Hydrogen saving benefits are not just limited to the econom- 


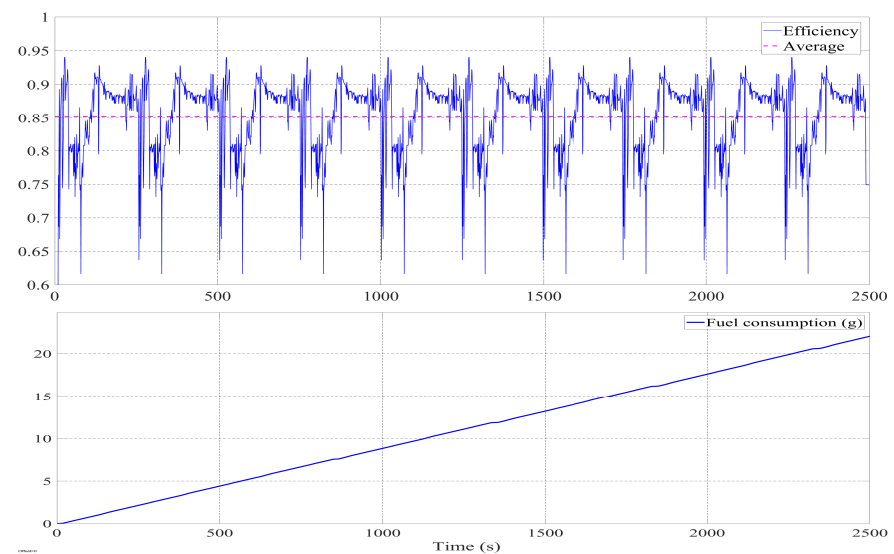

(a) RB-EMS

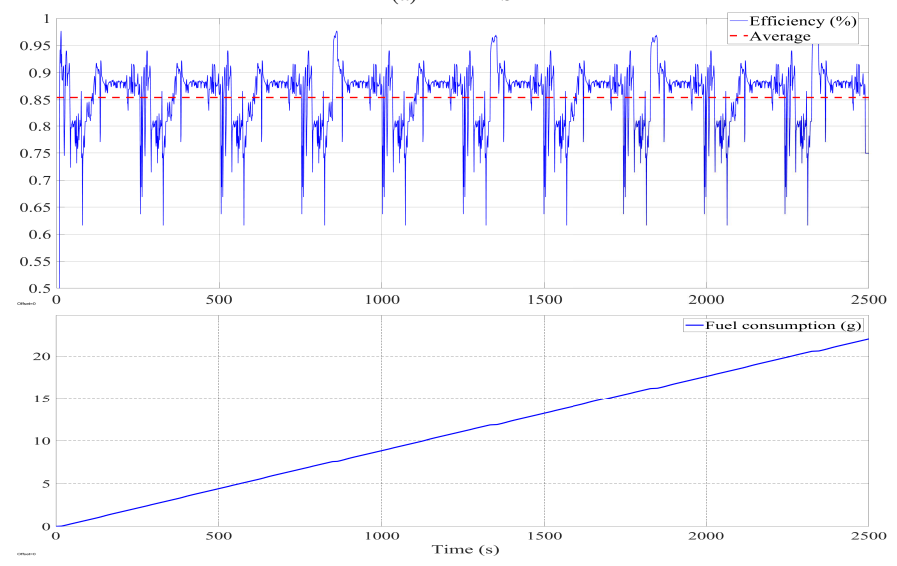

(b) FSRB-EMS

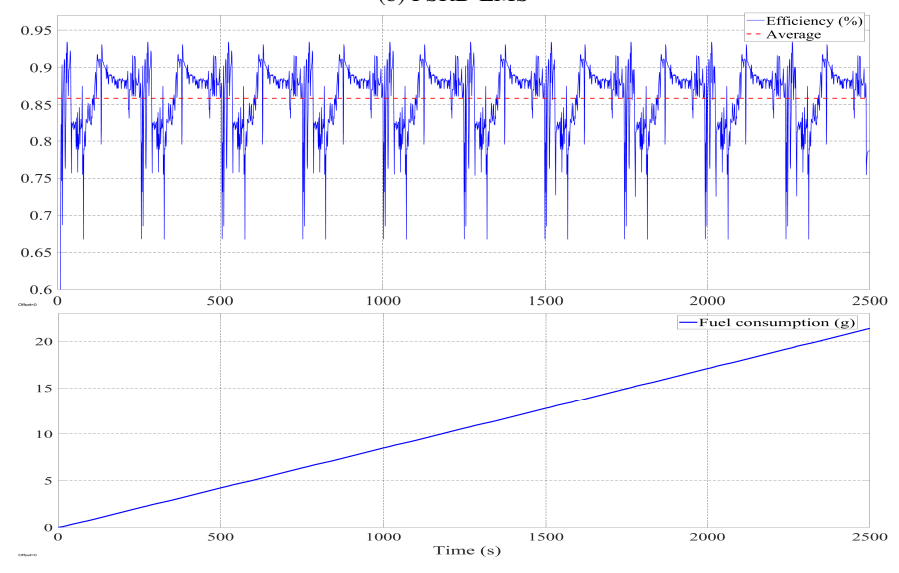

(c) ECMS

Figure 16: Efficiency and hydrogen consumption simulation results.

ical aspect. They have also a direct impact on the drone autonomy. Indeed, the number of cycle rounds to the ground charging station can be reduced and consequently more hydrogen will be saved while improving the drone operating efficiency. The endurance increase depends on the hydrogen tank. The greater energy density is, the greater autonomy increases. While MetaVista has achieved its world record of multirotor drone flight time (12h and 7min) in 2019 using with Intelligent Energy team $800 \mathrm{~W}$ fuel cell power module [15], the proposed improved EMS will lead to an endurance increase of $21.81 \mathrm{~min}$. Table 5 shows the expected increase in autonomy using the ECMS for some commercialized drones powered by Intelligent
Energy fuel cell power modules (FCPM).

Table 5: Expected autonomy improvement in Intelligent Energy's fuel cell powered drones.

\begin{tabular}{|c|c|c|c|c|}
\hline FCPM & Tank & Hydrogen & Flight time & $\begin{array}{l}\text { Endurance } \\
\text { improvement }\end{array}$ \\
\hline \multirow[t]{2}{*}{$650 \mathrm{~W}$} & $\begin{array}{l}2 \mathrm{~L} \\
276 \mathrm{~W} \mathrm{~h} \mathrm{~kg}^{-1}\end{array}$ & Compressed & $85 \mathrm{~min}$ & $+2.55 \mathrm{~min}$ \\
\hline & $6 \mathrm{~L}$ & Liquid & $10 \mathrm{~h} 50 \mathrm{~min}$ & $+19.5 \mathrm{~min}$ \\
\hline $2.4 \mathrm{~kW}$ & $\begin{array}{l}13 \mathrm{~L}, \\
4435 \mathrm{~W} \mathrm{~h} \mathrm{~kg}^{-1}\end{array}$ & Compressed & $\begin{array}{l}111 \text { min } \\
\text { kg payload })\end{array}$ & $+3.33 \mathrm{~min}$ \\
\hline $800 \mathrm{~W}$ & $6 \mathrm{~L}$ & Liquid & $12 \mathrm{~h} 7 \mathrm{~min}$ & $+21.81 \mathrm{~min}$ \\
\hline
\end{tabular}

\section{Conclusions}

This paper dealt with energy management for a hybrid power supply system of a fuel cell-powered quadcopter targeting endurance improvement. A commercially available Intelligent Energy drone was considered for the case study and real power consumption data were obtained by performing an experimental flight test of an electric hexacopter. Frequency separation rule-based and equivalent consumption minimization strategies were proposed to improve the system performance and hydrogen saving.

Comprehensive results had shown that the frequency separation rule-based method enabled supplying sources to be close to their nominal operating points while increasing their service lives. In addition, battery SOC was kept in its accepted range in contrary to a rule-based strategy. It had been also observed that battery hybridization increases the drone maneuverability by enabling fast power response and improves the hybrid power system efficiency and performance.

The equivalent consumption minimization strategy was proved capable of optimally distributing load power between the two sources leading to a $3 \%$ improvement in hydrogen use. This fuel economy has a direct impact on the drone autonomy reaching up to $21.81 \mathrm{~min}$ for the world flight test record performed in 2019 by MetaVista and intelligent Energy. Indeed, drone endurance improvement depends on the amount of carried hydrogen: the greater it is, the greater autonomy increases. The number of cycle rounds to the ground charging station during a given mission can also be minimized, leading to more hydrogen saving. The proposed hydrogen saving strategy will consequently lead to a decrease in the operating cost. Indeed, it can save up to $853.2 €$ per drone during one fuel cell module lifecyle considering the Intelligent Energy 650W fuel cell power module as a case study. For drones swarm, the number of deployed drones will multiply the gain.

\section{References}

[1] L. Duque, J. Seo, J. Wacker, Synthesis of unmanned aerial vehicle applications for infrastructures, Journal of Performance of Constructed Facilities 32 (4) (2018) 04018046 (aug 2018). doi:10.1061/(asce)cf.19435509.0001185 . 
[2] Y. Choi, B. Robertson, Y. Choi, D. Mavris, A multi-trip vehicle routing problem for small unmanned aircraft systems-based urban delivery, Journal of Aircraft 56 (6) (2019) 2309-2323 (nov 2019). doi:10.2514/1.c035473.

[3] K. Ma, Z. Qi, A human-centered design of general-purpose unmanned electric vehicle chassis for agriculture task payload, Journal of Computing and Information Science in Engineering 17 (3) (feb 2017) doi:10.1115/1.4034740.

[4] M. G. Fernandez, Y. A. Lopez, F. L.-H. Andres, On the use of unmanned aerial vehicles for antenna and coverage diagnostics in mobile networks, IEEE Communications Magazine 56 (7) (2018) 72-78 (jul 2018). doi:10.1109/mcom.2018.1700991.

[5] L. Ramadass, S. Arunachalam, Z. Sagayasree, Applying deep learning algorithm to maintain social distance in public place through drone technology, International Journal of Pervasive Computing and Communications 16 (3) (2020) 223-234 (2020). doi:10.1108/IJPCC-05-2020-0046.

[6] A. Kumar, K. Sharma, H. Singh, S. G. Naugriya, S. S. Gill, R. Buyya, A drone-based networked system and methods for combating coronavirus disease (covid-19) pandemic, Future Generation Computer Systems 115 (2020) 1-19 (2020). doi:10.1016/j.future.2020.08.046.

[7] Z. Pan, L. An, C. Wen, Recent advances in fuel cells based propulsion systems for unmanned aerial vehicles, Applied Energy 240 (2019) 473485 (apr 2019). doi:10.1016/j.apenergy.2019.02.079.

[8] , in: Theory, Design, and Applications of Unmanned Aerial Vehicles, CRC Press, 2016, pp. 47-101 (nov 2016). doi:10.1201/97813153711913.

URL https : //doi .org/10.1201\%2F9781315371191-3

[9] A. Gong, D. Verstraete, Fuel cell propulsion in small fixed-wing unmanned aerial vehicles: Current status and research needs, International Journal of Hydrogen Energy 42 (33) (2017) 21311-21333 (2017). doi:10.1016/j.ijhydene.2017.06.148.

[10] C. Depcik, T. Cassady, B. Collicott, S. P. Burugupally, X. Li, S. S. Alam, J. R. Arandia, J. Hobeck, Comparison of lithium ion batteries, hydrogen fueled combustion engines, and a hydrogen fuel cell in powering a small unmanned aerial vehicle, Energy Conversion and Management 207 (2020) 112514 (2020). doi:10.1016/j.enconman.2020.112514.

[11] Z. U. Bayrak, U. Kaya, E. Oksuztepe, Investigation of PEMFC performance for cruising hybrid powered fixed-wing electric UAV in different temperatures, International Journal of Hydrogen Energy 45 (11) (2020) 7036-7045 (feb 2020). doi:10.1016/j.ijhydene.2019.12.214.

[12] T. Donateo, A. Ficarella, L. Spedicato, A. Arista, M. Ferraro, A new approach to calculating endurance in electric flight and comparing fuel cells and batteries, Applied Energy 187 (2017) 807-819 (feb 2017). doi:10.1016/j.apenergy.2016.11.100.

[13] J. Apeland, D. Pavlou, T. Hemmingsen, Suitability analysis of implementing a fuel cell on a multirotor drone, Journal of Aerospace Technology and Management 12 (2020). doi:10.5028/jatm.v12.1172.

[14] HES multirotor drone, designed and built in US, has $3 \mathrm{~h}$ flight time, Fuel Cells Bulletin 2018 (12) (2018) 5 (2018). doi:10.1016/S14642859(18)30446-2.

[15] Intelligent Energy showcases drone fuel cell modules in japan, fuel cells bulletin, Fuel Cells Bulletin 2019 (8) (2019) 4 (2019). doi:10.1016/S1464-2859(19)30319-0.

[16] S. Ahmadi, S. Bathaee, A. H. Hosseinpour, Improving fuel economy and performance of a fuel-cell hybrid electric vehicle (fuel-cell, battery, and ultra-capacitor) using optimized energy management strategy, Energy Conversion and Management 160 (2018) 74-84 (2018). doi:10.1016/j.enconman.2018.01.020.

[17] Intelligent Energy, 650W Fuel Cell Power Module Specifications, (2019), Available at https://www.intelligent-energy.com/ our-products/uavs/, (Accessed on 03-12-2020).

[18] M. N. Boukoberine, Z. Zhou, M. Benbouzid, A critical review on unmanned aerial vehicles power supply and energy management: Solutions, strategies, and prospects, Applied Energy 255 (2019) 113823 (2019). doi:10.1016/j.apenergy.2019.113823.

[19] X. Zhang, L. Liu, G. Xu, Energy management strategy of hybrid pemfc-pv-battery propulsion system for low altitude uavs, in: 52nd AIAA/SAE/ASEE Joint Propulsion Conference, 2016, p. 5109 (2016). doi: $10.2514 / 6.2016-5109$.

[20] M. N. Boukoberine, Z. Zhou, M. Benbouzid, T. Donateo, A frequency separation rule-based power management strategy for a hybrid fuel cell- powered drone, in: IECON 2020 The 46th Annual Conference of the IEEE Industrial Electronics Society, IEEE, 2020, pp. 4975-4980 (2020). doi:10.1109/IECON43393.2020.9255118.

[21] X. Zhang, L. Liu, Y. Dai, T. Lu, Experimental investigation on the online fuzzy energy management of hybrid fuel cell/battery power system for uavs, International Journal of Hydrogen Energy 43 (21) (2018) 10094 10103 (2018). doi:10.1016/j.ijhydene.2018.04.075.

[22] Y. Xie, A. Savvaris, A. Tsourdos, Fuzzy logic based equivalent consumption optimization of a hybrid electric propulsion system for unmanned aerial vehicles, Aerospace Science and Technology 85 (2019) 13-23 (2019). doi:10.1016/j.ast.2018.12.001

[23] T. H. Oh, Conceptual design of small unmanned aerial vehicle with proton exchange membrane fuel cell system for long endurance mission, Energy Conversion and Management 176 (2018) 349-356 (2018). doi:10.1016/j.enconman.2018.09.036.

[24] Z. Ji, J. Qin, K. Cheng, H. Liu, S. Zhang, P. Dong, Thermodynamic analysis of a solid oxide fuel cell jet hybrid engine for long-endurance unmanned air vehicles, Energy Conversion and Management 183 (2019) 50-64 (2019). doi:10.1016/j.enconman.2018.12.076.

[25] E. Okumus, F. G. B. San, O. Okur, B. E. Turk, E. Cengelci, M. Kilic, C. Karadag, M. Cavdar, A. Turkmen, M. S. Yazici, Development of boron-based hydrogen and fuel cell system for small unmanned aerial vehicle, international journal of hydrogen energy 42 (4) (2017) 2691-2697 (2017). doi:10.1016/j.ijhydene.2016.09.009.

[26] Y.-T. Zhang, C. G. Claudel, M.-B. Hu, Y.-H. Yu, C.-L. Shi, Develop of a fuel consumption model for hybrid vehicles, Energy Conversion and Management 207 (2020) 112546 (2020). doi:10.1016/j.enconman.2020.112546.

[27] N. Bizon, Fuel saving strategy using real-time switching of the fueling regulators in the proton exchange membrane fuel cell system, Applied Energy 252 (2019) 113449 (2019). doi:10.1016/j.apenergy.2019.113449.

[28] N. Bizon, I. C. Hoarcă, Hydrogen saving through optimized control of both fueling flows of the fuel cell hybrid power system under a variable load demand and an unknown renewable power profile, Energy Conversion and Management 184 (2019) 1-14 (2019). doi:10.1016/j.enconman.2019.01.024.

[29] N. Bizon, Sensitivity analysis of the fuel economy strategy based on load-following control of the fuel cell hybrid power system, Energy Conversion and Management 199 (2019) 111946 (2019). doi:10.1016/j.enconman.2019.111946.

[30] N. Akhtar, J. Whidborne, A. Cooke, Real-time optimal techniques for unmanned air vehicles fuel saving, Proceedings of the Institution of Mechanical Engineers, Part G: Journal of Aerospace Engineering 226 (10) (2012) 1315-1328 (2012). doi:10.1177/0954410011418881.

[31] H. Wang, A. Gaillard, D. Hissel, A review of dc/dc converterbased electrochemical impedance spectroscopy for fuel cell electric vehicles, Renewable Energy 141 (2019) 124-138 (2019). doi: $10.1016 /$ j.renene.2019.03.130.

[32] F. Jeff, Iproduct Review: 3D Robotics RTF Y6 Multicopter, https://www.provideocoalition.com/3d-robotics-y6, (Accessed on 12-112020) (2014).

[33] T. Donateo, L. Spedicato, D. P. Placentino, Design and performance evaluation of a hybrid electric power system for multicopters, Energy Procedia 126 (2017) 1035-1042 (2017). doi:10.1016/j.egypro.2017.08.310.

[34] W. Johnson, Rotorcraft aeromechanics, Vol. 36, Cambridge University Press, 2013 (2013). doi:10.1017/CBO9781139235655.

[35] M. N. Boukoberine, Z. Zhou, M. Benbouzid, T. Donateo, Frequency separation-based power management strategy for a fuel cell-powered drone, in: 2020 2nd International Conference on Smart Power \& Internet Energy Systems, IEEE, 2020 (2020). doi:10.1109/spies48661.2020.9242975.

[36] B. Lee, S. Kwon, P. Park, K. Kim, Active power management system for an unmanned aerial vehicle powered by solar cells, a fuel cell, and batteries, IEEE transactions on Aerospace and Electronic Systems 50 (4) (2014) 3167-3177 (2014). doi:10.1109/taes.2014.130468.

[37] Y. Wu, A. Ravey, D. Chrenko, A. Miraoui, Demand side energy management of ev charging stations by approximate dynamic programming, Energy Conversion and Management 196 (2019) 878-890 (2019). doi:10.1016/j.enconman.2019.06.058.

[38] X. Lü, Y. Wu, J. Lian, Y. Zhang, C. Chen, P. Wang, L. Meng, Energy management of hybrid electric vehicles: A review of energy op- 
timization of fuel cell hybrid power system based on genetic algorithm, Energy Conversion and Management 205 (2020) 112474 (2020). doi:10.1016/j.enconman.2020.112474.

[39] Y. Wang, Z. Yang, M. Mourshed, Y. Guo, Q. Niu, X. Zhu, Demand side management of plug-in electric vehicles and coordinated unit commitment: A novel parallel competitive swarm optimization method, Energy conversion and management 196 (2019) 935-949 (2019). doi:10.1016/j.enconman.2019.06.012.

[40] H. Li, A. Ravey, A. N'Diaye, A. Djerdir, Online adaptive equivalent consumption minimization strategy for fuel cell hybrid electric vehicle considering power sources degradation, Energy Conversion and Management 192 (2019) 133-149 (2019). doi:10.1016/j.enconman.2019.03.090.

[41] H. Dong, Z. Zhao, J. Fu, J. Liu, J. Li, K. Liang, Q. Zhou, Experiment and simulation investigation on energy management of a gasoline vehicle and hybrid turbocharger optimization based on equivalent consumption minimization strategy, Energy Conversion and Management 226 (2020) 113518 (2020). doi:10.1016/j.enconman.2020.113518.

[42] P. García, J. P. Torreglosa, L. M. Fernández, F. Jurado, Viability study of a fc-battery-sc tramway controlled by equivalent consumption minimization strategy, International journal of hydrogen energy 37 (11) (2012) 9368-9382 (2012). doi:10.1016/j.ijhydene.2012.02.184.

[43] W. Zhang, J. Li, L. Xu, M. Ouyang, Optimization for a fuel cell/battery/capacity tram with equivalent consumption minimization strategy, Energy Conversion and Management 134 (2017) 59-69 (2017). doi:10.1016/j.enconman.2016.11.007.

[44] J. P. Torreglosa, F. Jurado, P. García, L. M. Fernández, Hybrid fuel cell and battery tramway control based on an equivalent consumption minimization strategy, Control Engineering Practice 19 (10) (2011) 11821194 (2011). doi:10.1016/j.conengprac.2011.06.008.

[45] S. N. Motapon, L.-A. Dessaint, K. Al-Haddad, A comparative study of energy management schemes for a fuel-cell hybrid emergency power system of more-electric aircraft, IEEE Transactions on Industrial Electronics 61 (3) (2013) 1320-1334 (2013). doi:10.1109/tie.2013.2257152.

[46] M. Meiler, O. Schmid, M. Schudy, E. P. Hofer, Dynamic fuel cell stack model for real-time simulation based on system identification, Journal of Power Sources 176 (2) (2008) 523-528 (2008). doi:10.1016/j.jpowsour.2007.08.051.

[47] I. S. Martín, A. Ursúa, P. Sanchis, Modelling of PEM fuel cell performance: Steady-state and dynamic experimental validation, Energies 7 (2) (2014) 670-700 (feb 2014). doi:10.3390/en7020670.

[48] R. Ferrero, M. Marracci, M. Prioli, B. Tellini, Simplified model for evaluating ripple effects on commercial PEM fuel cell, International Journal of Hydrogen Energy 37 (18) (2012) 13462-13469 (sep 2012). doi:10.1016/j.ijhydene.2012.06.036.

[49] S. Njoya, O. Tremblay, L.-A. Dessaint, A generic fuel cell model for the simulation of fuel cell vehicles, in: 2009 IEEE Vehicle Power and Propulsion Conference, IEEE, 2009, pp. 1722-1729 (2009). doi:10.1109/vppc.2009.5289692.

[50] O. Tremblay, L.-A. Dessaint, Experimental validation of a battery dynamic model for EV applications, World Electric Vehicle Journal 3 (2) (2009) 289-298 (jun 2009). doi:10.3390/wevj3020289.

[51] S. Chakraborty, H.-N. Vu, M. M. Hasan, D.-D. Tran, M. E. Baghdadi, O. Hegazy, Dc-dc converter topologies for electric vehicles, plug-in hybrid electric vehicles and fast charging stations: State of the art and future trends, Energies 12 (8) (2019) 1569 (2019). doi:110.3390/en12081569.

[52] J. Sisco, F. Harrington, P. Robinson, Drone Refueling, Tech. rep., Ballard Power Systems Inc., (October 2018), Available at https://www.ballard.com/docs/default-source/uav/uav_ hydrogen-refueling_wp_oct_18.pdf?sfvrsn=ff62c080_2 (Accessed on 03-12-2020). 